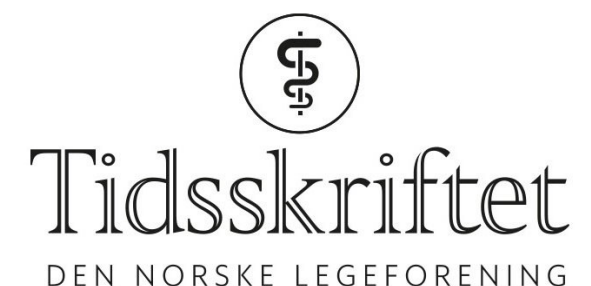

DEN NORSKE LEGEFORENING

\title{
Leger krever klimahandling nå!
}

DEBATT

\section{JOHN GUNNAR MAELAND}

E-post: john.meland@uib.no

John Gunnar Mæland er professor emeritus i sosialmedisin, tidligere leder og nåværende rådsmedlem i Norske leger mot atomvåpen.

Forfatteren har fylt ut ICMJE-skjemaet og oppgir ingen interessekonflikter.

\section{LASSE PIHLSTRØM}

Lasse Pihlstrøm er lege i spesialisering og postdoktorstipendiat ved Nevrologisk avdeling, Oslo universitetssykehus.

Forfatteren har fylt ut ICMJE-skjemaet og oppgir ingen interessekonflikter.

\section{KNUT MORK SKAGEN}

Knut Mork Skagen er lege i spesialisering i barne- og ungdomspsykiatri ved St. Olavs hospital og nestleder i styret for Norske leger mot atomvåpen.

Forfatteren har fylt ut ICMJE-skjemaet og oppgir ingen interessekonflikter.

\section{GUNNAR KVÅLE}

Gunnar Kvåle er lege, professor emeritus og tidligere leder for Senter for internasjonal helse ved Universitetet i Bergen. Han er styremedlem i Besteforeldrenes klimaaksjon. Forfatteren har fylt ut ICMJE-skjemaet og oppgir ingen interessekonflikter.

Leger krever klimahandling nå! er tittelen på et opprop fra Legenes klimaaksjon. Klimakrisen er en helsekrise, og vi krever umiddelbare og radikale endringer i norsk klima- og energipolitikk. Leger og legestudenter oppfordres til å signere oppropet.

Oppropet som ble lansert 14. oktober av Legenes klimaaksjon, et initiativ fra ni samfunnsengasjerte norske leger, henvender seg til Stortinget og har følgende ordlyd:

Som leger har vi en etisk forpliktelse til å varsle når stor helsefare truer. Derfor varsler vi nå: Klimakrisen er en helsekrise. Global oppvarming er den største trussel mot verdens folkehelse i det 21. århundret.

Norges klima- og energipolitikk forverrer krisen. Hvis andre land gjør som Norge, vil verden styre mot en global oppvarming på $3{ }^{\circ} \mathrm{C}$ eller mer i dette århundret. Dette vil føre til en lang rekke helseutfordringer og betydelig folkedød. Heteslag, underernæring, sult, diarésykdommer og andre infeksjoner vil øke og vil rasere framgangen i global helse som er oppnådd de siste tiårene.

Hete, tørke, sykloner, havstigning og flom vil ramme en stadig større del av verdens befolkning og gjøre store deler av verden ubeboelig. Mange hundre millioner mennesker vil bli tvunget på flukt og risiko for konflikter og krig vil øke. De fattigste i land nær ekvator vil rammes først og sterkest, men ingen land vil være uberørt av klimaendringenes 
helsekonsekvenser.

For å hindre dette kreves raske og gjennomgripende endringer i politikk og samfunn. Som et rikt land ansvarlig for store globale klimagassutslipp, har Norge et spesielt moralsk og $\emptyset$ konomisk ansvar for å gå i front i klimakampen.

Gode klimatiltak er også gode helsetiltak. Ifølge Verdens helseorganisasjon vil helsegevinstene alene langt overgå kostnadene ved å nå Paris-avtalens mål. Et samfunn som evner å forebygge de største klimaendringene er et friskere og mer rettferdig samfunn.

Vi undertegnede norske leger og legestudenter ber Stortinget sørge for at Norge

- stopper oljeletingen og starter nødvendig utfasing av produksjon av olje og gass nå.

- kutter egne klimagassutslipp mer enn det som ifølge FNs klimapanel er nødvendig for å begrense global oppvarming til godt under $2{ }^{\circ} \mathrm{C}$.

- bidrar langt mer til at lavinntektsland oppnår reduksjon i klimagassutslipp og blir bedre i stand til å møte de helsemessige og sosiale utfordringene som klimakrisen innebærer.

Oppropet er ved lanseringen allerede signert av mer enn 6o kjente norske leger, som representerer et bredt spekter av spesialiteter og ulike yrkesbakgrunner (1). Alle leger og legestudenter oppfordres nå til å undertegne oppropet på www.legenesklimaaksjon.no før dette overleveres Stortinget i forkant av FNs klimatoppmøte (COP25) i Santiago, Chile, primo desember 2019 .

\section{Hvorfor Legenes klimaaksjon?}

Legenes klimaaksjon springer ut av erkjennelsen av at global oppvarming er den største folkehelsetrusselen i dette århundret, ved siden av faren for atomkrig. Leger har bekjempet atomvåpen i nærmere 40 år, nå må vi ta med oss disse erfaringene i kampen mot klimakrisen. I begge tilfeller står vi overfor en alvorlig risiko som resultat av menneskelig teknologi og utvikling. Det betyr samtidig at de kan avverges gjennom menneskelig handling. Begge truslene krever bredt folkelig og politisk engasjement basert på kunnskap og forståelse av hva som står på spill. De alvorlige humanitære konsekvensene må vekke oss til handling. Uten en slik kollektiv mobilisering vil kortsiktige økonomiske og politiske interesser motvirke nødvendige tiltak for å redusere truslene.

Leger har også mulighet til å skape håp ved å vise til at forebyggende tiltak og metoder for nødvendig skadereduksjon finnes og kan gi bedring (2). Klimakrisen er en lenge varslet helsekatastrofe, som har vært møtt med benekting, fortrengning, likegyldighet og apati. Men nå er en internasjonal grasrotbevegelse i ferd med å vokse seg sterk, ikke minst blant ungdom. Leger og andre grupper med kunnskap og innflytelse må støtte opp om denne mobiliseringen, på samme måte som i 1980-årene, da en kraftfull allianse i sivilsamfunnet maktet å bryte atomopprustningens onde spiral (3).

Et samfunn som evner å forebygge de største klimaendringene er et friskere og mer rettferdig samfunn

I England har nylig mer enn 1 ooo leger skrevet under på et opprop om at Paris-avtalen må oppfylles (4). I USA har mer enn 70 organisasjoner for helsearbeidere, blant disse den amerikanske legeforeningen og flere spesialistforeninger, nylig gått ut med et opprop hvor det kreves at USA må gjennomføre et raskt skifte fra kull, olje og gass til fornybar energi (5). Oppropet fra Legenes klimaaksjon slutter seg til disse initiativene med tilsvarende krav til norske politikere. Vi oppfordrer våre kolleger til å støtte oppropet og aksjonen. 
1. Legenes klimaaksjon. https://legenesklimaaksjon.no/ Lest 10.10.2019.

2. Kvåle G, Skagen KM, Fadnes LT et al. Klimakrisen - vårt ansvar som leger. Tidsskr Nor Legeforen 2019; 139. doi: 10.4045/tidsskr.19.0o81. [PubMed][CrossRef]

3. Wittner LS. Confronting the bomb. A short history of the world nuclear disarmament movement. Stanford, CA: Stanford University Press, 2009.

4. Underwood J, Middleton J, Penchton D et al. Doctors against climate catastrophe. The Guardian 27.6.2019.

https://www.theguardian.com/environment/2019/jun/27/doctors-against-climate-catastrophe Lest 10.10.2019.

5. Pullano NUS. Medical Groups Warn Candidates. Climate Change Is a 'Health Emergency'. Inside Climate News.

https://insideclimatenews.org/news/24062019/us-health-groups-declare-climate-change-public-health -emergency-urge-fossil-fuel Lest 10.10.2019.

Publisert: 6. november 2019. Tidsskr Nor Legeforen. DOI: 10.4045/tidsskr.19.0657

Mottatt 11.10.2019, godkjent 24.10.2019.

(C) Tidsskrift for Den norske legeforening 2020. Lastet ned fra tidsskriftet.no 